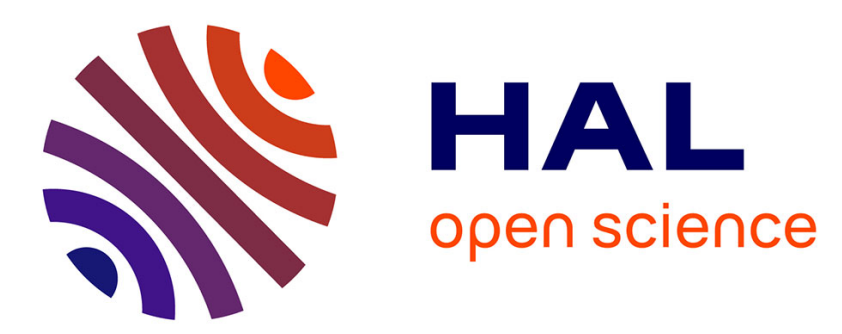

\title{
Geographic distribution and ecology of two species of Orsillus (Hemiptera: Lygaeidae) associated with cones of native and introduced Cupressaceae in Europe and the Mediterranean Basin
}

\author{
Gaelle Rouault, Raffaella Cantini, Andrea Battisti, Alain Roques
}

\section{To cite this version:}

Gaelle Rouault, Raffaella Cantini, Andrea Battisti, Alain Roques. Geographic distribution and ecology of two species of Orsillus (Hemiptera: Lygaeidae) associated with cones of native and introduced Cupressaceae in Europe and the Mediterranean Basin. Canadian Entomologist, 2005, 137 (4), pp.450470. hal-02679894

\author{
HAL Id: hal-02679894 \\ https://hal.inrae.fr/hal-02679894
}

Submitted on 31 May 2020

HAL is a multi-disciplinary open access archive for the deposit and dissemination of scientific research documents, whether they are published or not. The documents may come from teaching and research institutions in France or abroad, or from public or private research centers.
L'archive ouverte pluridisciplinaire HAL, est destinée au dépôt et à la diffusion de documents scientifiques de niveau recherche, publiés ou non, émanant des établissements d'enseignement et de recherche français ou étrangers, des laboratoires publics ou privés. 


\title{
Geographic distribution and ecology of two species of Orsillus (Hemiptera: Lygaeidae) associated with cones of native and introduced Cupressaceae in Europe and the Mediterranean Basin
}

\author{
Gaelle Rouault \\ INRA, station de Zoologie Forestière, B.P. 20619 Ardon, 45166 Olivet CEDEX, France \\ Raffaella Cantini \\ Istituto per la Protezione delle Piante, CNR, 50019 Sesto Fiorentino, Firenze, Italy \\ Andrea Battisti \\ University of Padova, DAAPV-Entomology, Agripolis, 35020 Legnaro PD, Italy \\ Alain Roques ${ }^{1}$ \\ INRA, station de Zoologie Forestière, B.P. 20619 Ardon, 45166 Olivet CEDEX, France
}

\begin{abstract}
In the Mediterranean Basin, two species of true seed bugs in the genus Orsillus Dallas, O. maculatus Fieber and $O$. depressus Mulsant et Rey, share the exploitation of seed cones of Cupressaceae for feeding and reproduction and may carry spores of the pathogenic fungus Seiridium cardinale Sutton \& Gibson, responsible for the cypress bark canker disease. We compared the life history of the two species. A total of 89 cone collections carried out in 10 Mediterranean countries confirmed that $O$. maculatus is most closely associated with Cupressus sempervirens L., although it may also infest some other Cupressus L. species and, more rarely, species of Chamaecyparis Spach. Orsillus depressus appears to be less host-specific, being capable of feeding and ovipositing on most of the native and exotic species of Juniperus L., Cupressus, and Chamaecyparis. On C. sempervirens, the abundance of each Orsillus species follows an inverted longitudinal gradient along the Mediterranean Basin, probably corresponding to the pathway of introduction of this tree species from its native eastern range towards western Europe. The dominance of $O$. maculatus progressively decreases from east to west, whereas $O$. depressus becomes dominant in the Iberian Peninsula. By contrast, O. depressus is the dominant seed bug on other Cupressaceae all over Europe and the Mediterranean Basin. In the area in which $C$. sempervirens has been introducted, both Orsillus species may live on the same tree, but morphological variability of both adults and nymphs often hinders accurate identification of the species. Based on frequency distribution, the relative length of the rostrum compared with that of the body seems to be a diagnostic character for specific identification of nymphs of the last two instars.
\end{abstract}

Résumé-Dans le Bassin Méditerranéen, deux punaises des graines du genre Orsillus Dallas, $O$. maculatus Fieber et $O$. depressus Mulsant et Rey, se partagent l'exploitation des cônes de $\mathrm{Cu}$ pressacées pour leur nutrition et leur reproduction. Ces deux espèces transportent les spores d'un champignon pathogène, Seiridium cardinale Sutton \& Gibson, responsable de la maladie du chancre cortical du cyprès. Le cycle biologique respectif des deux espèces est comparé. L'analyse de 89 récoltes de cônes réalisées dans 10 pays méditerranéens a confirmé que $O$. maculatus est plus étroitement associée à Cupressus sempervirens L. bien qu'elle puisse aussi se retrouver sur d'autres espèces de Cyprès et, mais plus rarement, de Chamaecyparis Spach. Orsillus depressus semble plus oligophage, étant capable de se nourrir et de se reproduire sur la plupart des espèces natives et exotiques de Cupressacées. Sur C. sempervirens, l'abondance relative de chaque espèce suit un gradient longitudinal inversé le long du Bassin Méditerranéen, qui correspond vraisemblablement à la route d'introduction de l'essence-hôte depuis son aire d'origine orientale vers l'Europe occidentale. La dominance d'O. maculatus décroît progressivement d'est

Received 11 May 2004. Accepted 22 June 2005.

${ }^{1}$ Corresponding author (e-mail: Alain.Roques@orleans.inra.fr). 
en ouest, $O$. depressus devenant l'espèce principale dans la Péninsule Ibérique. Sur les autres Cupressaceae, $O$. depressus est l'espèce prédominante dans l'ensemble de l'Europe comme dans le Bassin Méditerranéen. Dans l'aire d'introduction de C. sempervirens, les deux espèces cohabitent parfois sur un même arbre, mais l'identification de chaque espèce est rendue difficile par des variations morphologiques chez les adultes et les larves. Sur la base de la distribution des fréquences, la longueur relative du rostre comparée à celle du corps semble constituer un caractère diagnostique pour la différenciation des larves des deux derniers stades de chaque espèce.

\section{Introduction}

Trees and shrubs of Cupressaceae cover a large part of Europe, especially in the Mediterranean Basin, where evergreen cypress, Cupressus sempervirens L., has been introduced on a large scale since the time of the ancient Greeks (Baumann 1982). However, several Cupressaceae species (e.g., Cupressus atlantica Gaussen, Cupressus dupreziana A. Camus, and Juniperus thurifera L.) face extinction in parts of their native range, whereas $C$. sempervirens largely suffers from the disastrous spread of an exotic disease, cypress bark canker (Teissier et al. 1999). Since the 1990s, several studies have attempted to establish the part played by cone and seed insects in limiting the potential for natural regeneration of Mediterranean cypresses and junipers (Guido et al. 1995; Garcia 1998; Roques et al. 1999b; Roques and Battisti 1999; Battisti et al. 2000; Blasco-Zumeta 2000; Garcia et al. 2000) and in disseminating pathogenic fungi (Battisti et al. 1999, 2003; Ramos and Caetano 1999). Seed bugs have always appeared to constitute a key element of the cone entomofauna, but their bionomics have remained unclear because they are external predators of seed cones and thus are usually difficult to sample.

In Europe and the Mediterranean Basin, Cupressaceae species host four species of seed bugs in the genus Orsillus Dallas (Hemiptera: Lygaeidae) (Dioli 1991; Schuh and Slater 1995; Péricart 1998). However, two of these species seem either localized (O. pinicanariensis Lindberg in the Canary islands) or scarce (O. reyi Puton), whereas $O$. maculatus Fieber and $O$. depressus Mulsant $e t$ Rey have been frequently recorded in a number of countries (for details see Péricart 1998).

These latter two species of Orsillus have been reported to cause significant damage to seed crops in seed orchards as well as natural stands and plantations (Roques et al. 1999b; Battisti et al. 2000). They have also been shown to carry on their body spores of a pathogenic fungus, Seiridium cardinale Sutton \& Gibson, responsible for the cypress bark canker disease in plantations and natural forests of C. sempervirens in Europe and the Mediterranean area (Wagener 1939; Colombari 1996; Cantini 1997; Graniti 1998). Seiridium cardinale was probably introduced from California together with a Californian cypress, Cupressus macrocarpa Hart., which was imported to provide windbreak hedges in western Europe. The cypress bark canker disease was first noticed in France (Barthelet and Vinot 1944) and then spread rapidly all over southern Europe (Grasso 1951; Strout 1970; Graniti 1998; Battisti et al. 1999). It is not yet clear how the pathogenic fungus shifted from C. macrocarpa to C. sempervirens. Battisti et al. $(1997,1999)$ showed that the occurrence of $S$. cardinale on $C$. sempervirens is strongly associated with the presence of $O$. maculatus, which seems to trigger the dissemination of the fungal spores, but $O$. depressus was recently suggested to play a similar role in Portugal (Ramos and Caetano 1999). In addition, only $O$. depressus has been reported to use C. macrocarpa as a host tree (Dioli 1991).

It has been reported that the adults of $O$. maculatus and $O$. depressus are easily separated by the length of the rostrum relative to that of the body. In $O$. maculatus, the rostrum usually reaches the extremity of the abdomen, whereas it reaches only the mid-abdomen in O. depressus (Dioli 1991; Schuh and Slater 1995; Péricart 1998). However, only mean values are available for body length and rostrum length; the range of the ratio of rostrum length to body length remains unknown. Moreover, no data exist for such a ratio in nymphs and it is not yet possible to identify to species level samples containing only Orsillus nymphs. Under laboratory conditions, five developmental instars have been observed for the nymphs of $O$. maculatus reared on $C$. sempervirens; the overall development from egg to adult takes approximately 61 days, and the species is considered multivoltine (Guido et al. 1995; Battisti et al. 1997; Rouault 2002). In the field, $O$. maculatus oviposited on cypress cones 
preferentially in the emergence holes of a cypress seed chalcid, Megastigmus wachtli Seitner (Hymenoptera: Torymidae), or on the inner side of partly opened cone scales (Guido et al. 1995; Battisti et al. 1997, 2003; Rouault 2002). Chalcid holes appeared to protect bug eggs from parasitoid attacks and mechanical injuries (Rouault et al. 2000). In contrast, the life history of $O$. depressus remains quite unknown.

Data on the host range and distribution of the two species are confusing. The distribution range of $O$. maculatus is considered to cover essentially the borders of the Mediterranean Sea (Guido et al. 1995; Péricart 1998; Roques et al. $1999 b$ ). This species has been primarily reported on $C$. sempervirens but there are some punctual records on junipers and pines (Pinus L.; Pinaceae) (Lindberg 1948; Kiritchenko 1951; Roques 1983; see also references in Péricart 1998). Recently, O. maculatus was also reported on Cupressus arizonica Greene in Algeria (Bouaziz and Chakali 1997). The geographic distribution of $O$. depressus is reportedly larger, covering Europe from west to north and east until Tadzhikistan (Aukema 1988; Reichling 1988; Hawkins 1989; Péricart 1998). It also seems to have a wider host range, having been recorded on Mediterranean species of Biota D. Don ex Endl., Cupressus L., and Juniperus L. (Ben Jamaa and Roques 1999; El Alaoui El Fels 1999a, 1999b) but also Pinus (Mulsant and Rey 1872; Péricart 1998) and several exotic species of Chamaecyparis Spach, Cupressus, and Thuja L. (Péneau 1927; Cleu 1950, 1953; Dupuis 1965; Roques 1983; Aukema 1988; Dioli 1991; El Alaoui El Fels 1997; Péricart 1998; Roques et al. 1999b; Blasco-Zumeta 2000; Rouault et al. 2000). However, most of these records were based on the observation of a few individuals, sometimes even a single specimen, without any clear evidence of feeding and reproduction on these tree species.

Therefore, our objectives were to clarify the host range and distribution of both species to identify possible pathways for dissemination of $S$. cardinale. We also intended to precisely determine the life history of each bug species by rearing $O$. depressus under laboratory conditions and recording the seasonal fluctuations of O. maculatus abundance in cypress cones. Finally, we aimed to define diagnostic, easy-touse morphological criteria allowing accurate identification of both nymphs and adults. For these purposes, standardized cone collections were carried out for several years throughout western, southern, and eastern Europe, Asia Minor, and northern Africa. All the native species, as well as the massively planted exotic species of Cupressaceae, were surveyed.

\section{Materials and methods}

\section{Geographical distribution and host range of Orsillus seed bugs}

A total of 57 cone samplings were carried out on C. sempervirens during 1995-2003 at 56 locations in Europe, Asia Minor, and North Africa. Samples were collected from 7 sites in the native range of evergreen cypress (the Aegean Islands, Crete, and Turkey) and 49 sites in the introduced range (Corsica, continental France, continental Greece, Israel, Italy, Montenegro, Morocco, Portugal, Spain, and Tunisia) (Table 1, Fig. 1). In addition, 32 cone samples were collected from other native and introduced Cupressaceae species growing in the same geographic areas: at 7 sites where cones of C. sempervirens were also collected, and at 16 additional sites. For comparison, cone collections were also carried out in China, South Africa, and California to survey the presence of Orsillus species on introduced and native Cupressus species in countries where cypress canker is present.

For $C$. sempervirens, we collected 30 mature, 3-year-old cones per tree. From 1 to 170 trees were sampled per site, depending on cone abundance. Open cones, likely to contain nymphs or adult seed bugs, were immediately put in sealed plastic boxes, whereas closed cones were stored in paper bags until analysis at the laboratory. Similarly, for Chamaecyparis and Juniperus spp. we collected 30 mature cones per tree, but we also collected foliage where Orsillus species may hide. In these species, 2-5 cone-bearing branches per tree were each beaten 5 times.

Cone analysis was conducted within 10 days following collection. Each cone was first examined for the presence of nymphs and adults of Orsillus spp. and for emergence holes of a cypress seed chalcid, M. wachtli. Orsillus species were identified based on the length of the rostrum compared with the body length, but also using the body color (i.e., darker for $O$. maculatus than for $O$. depressus, and with more reddish parts for $O$. depressus) and the shape of the pronotal spot (i.e., usually a black dot at the center of the pronotum for 
Rouault et al.

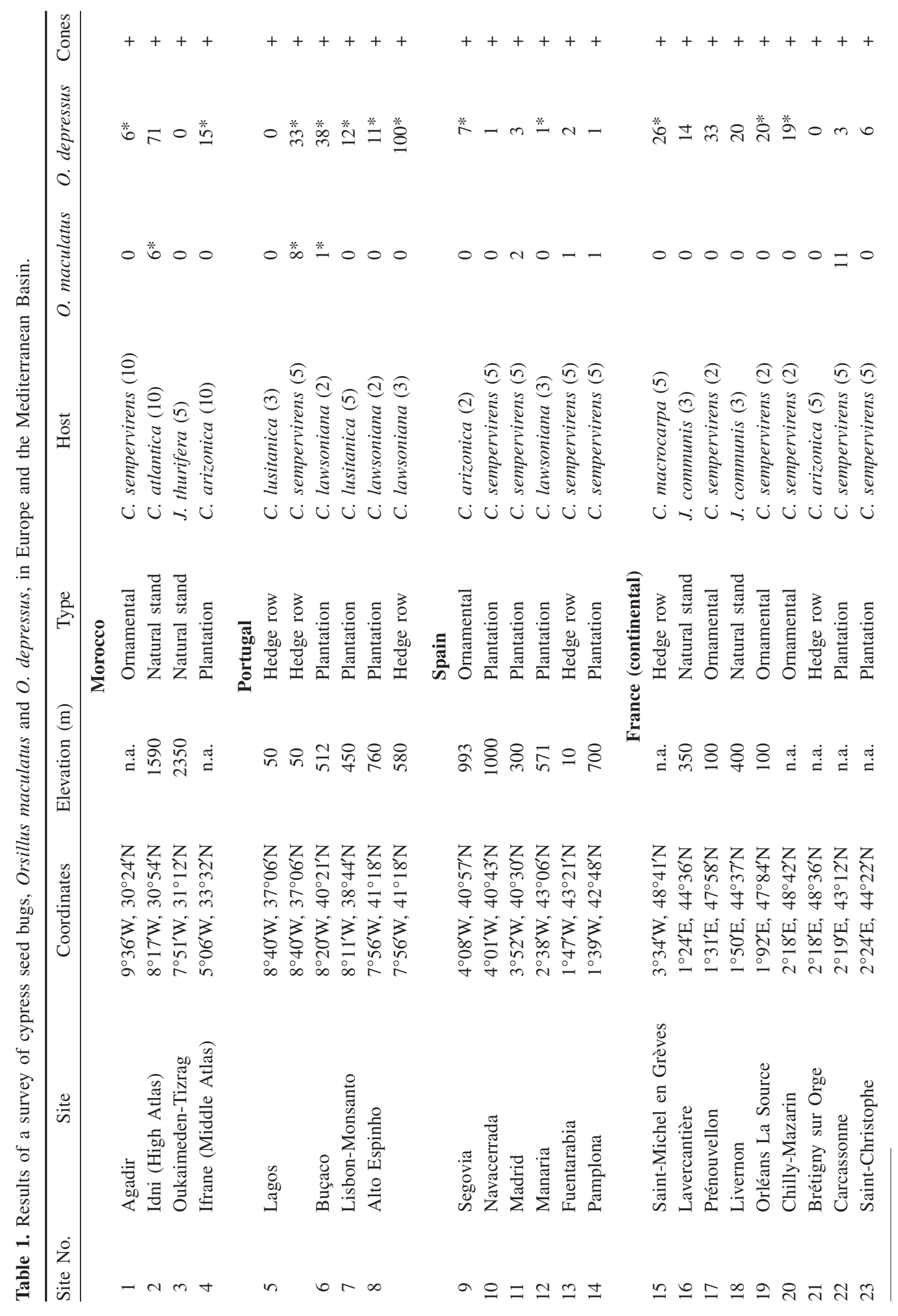




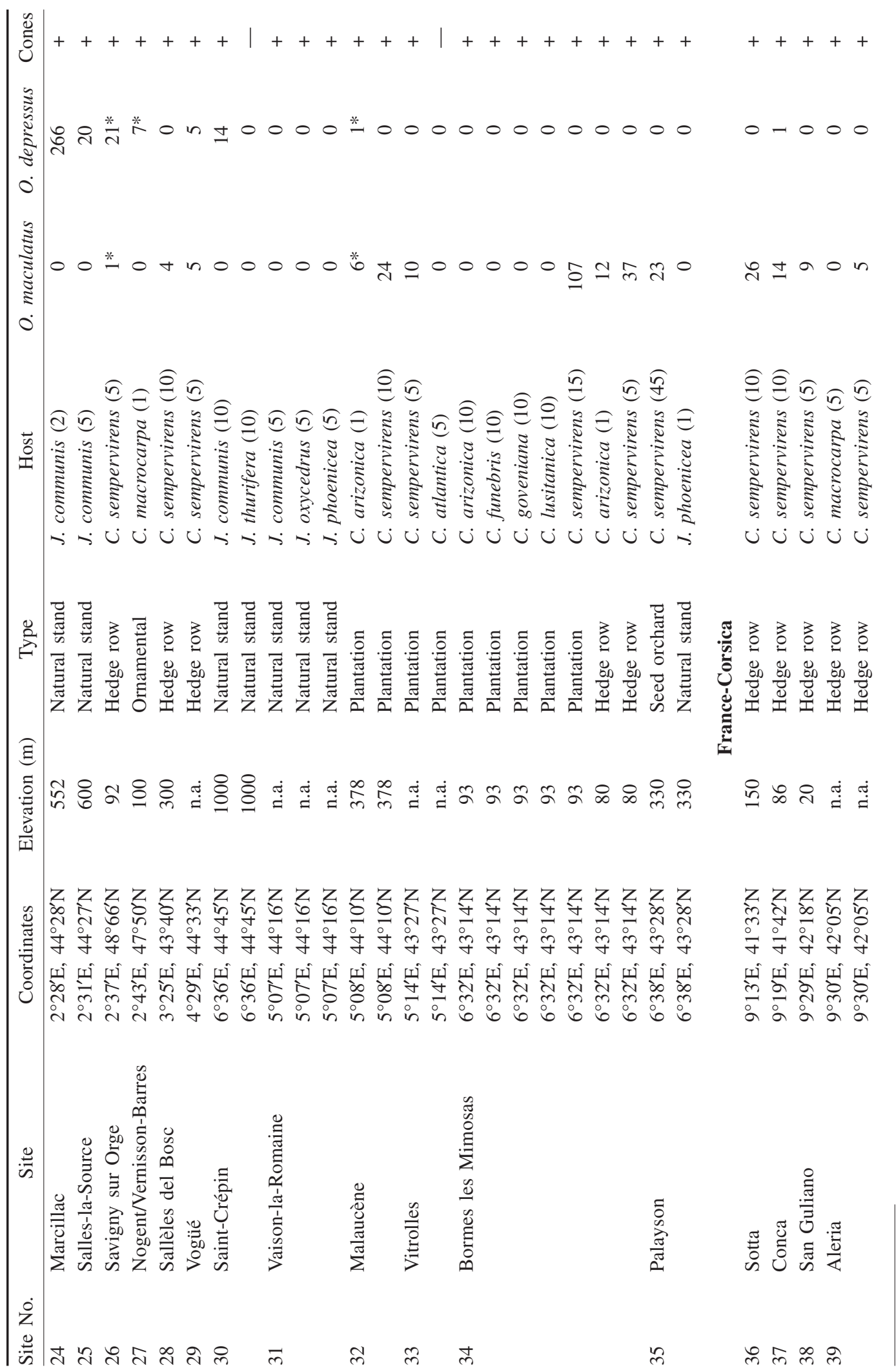


Rouault et al.

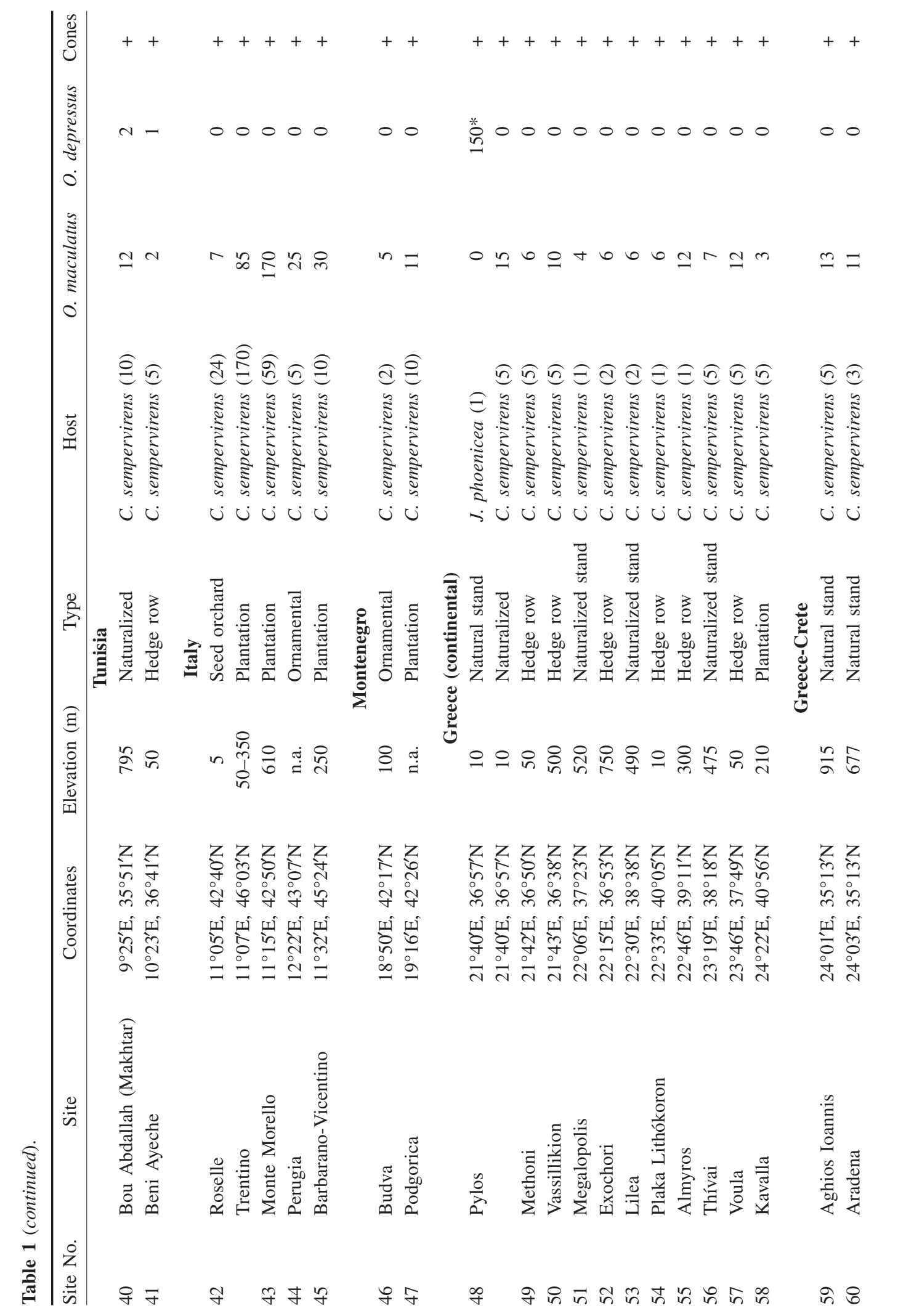




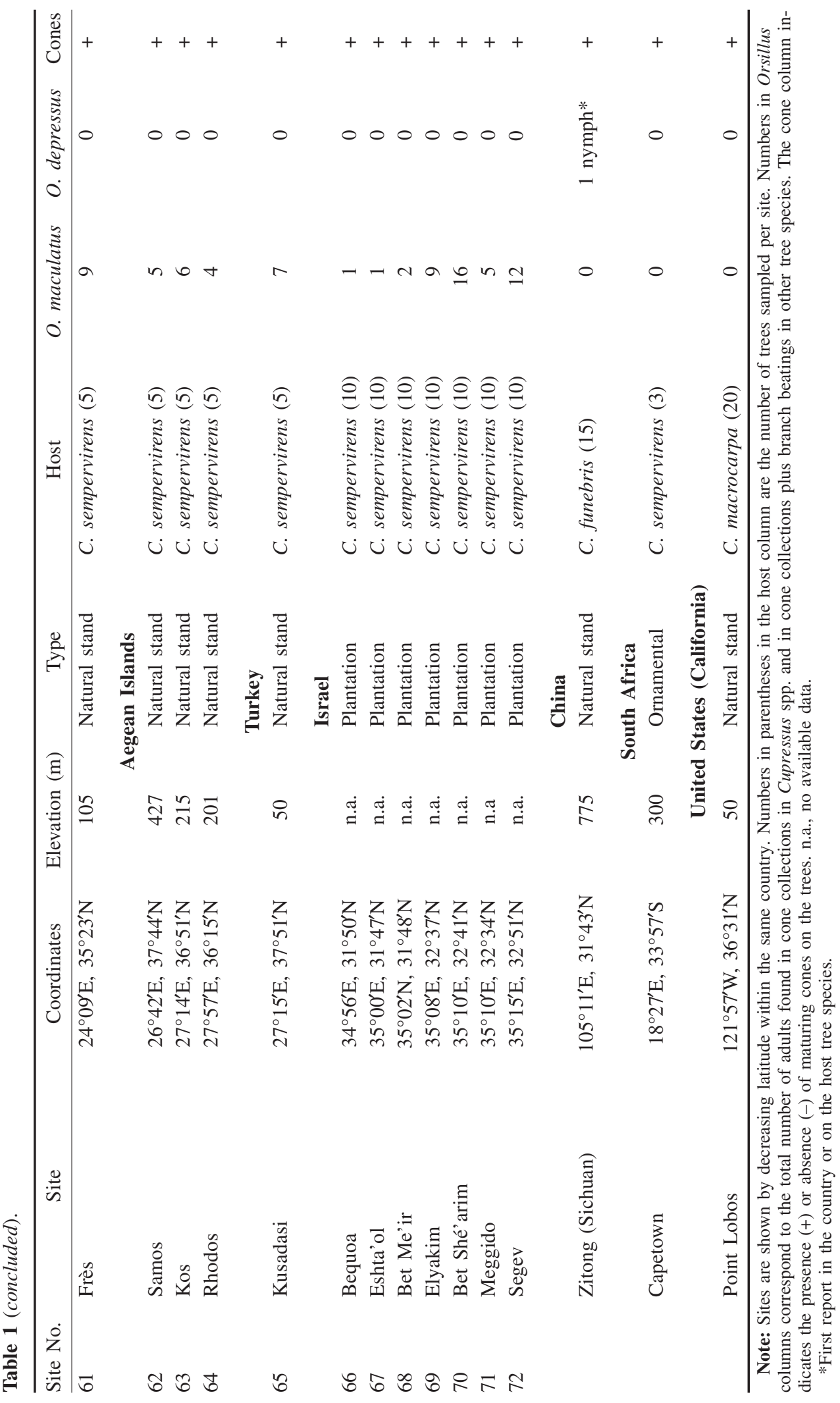


Fig. 1. Locations of the Cupressaceae stands and plantations sampled during the study. The numbers correspond to the site numbers listed in Table 1.

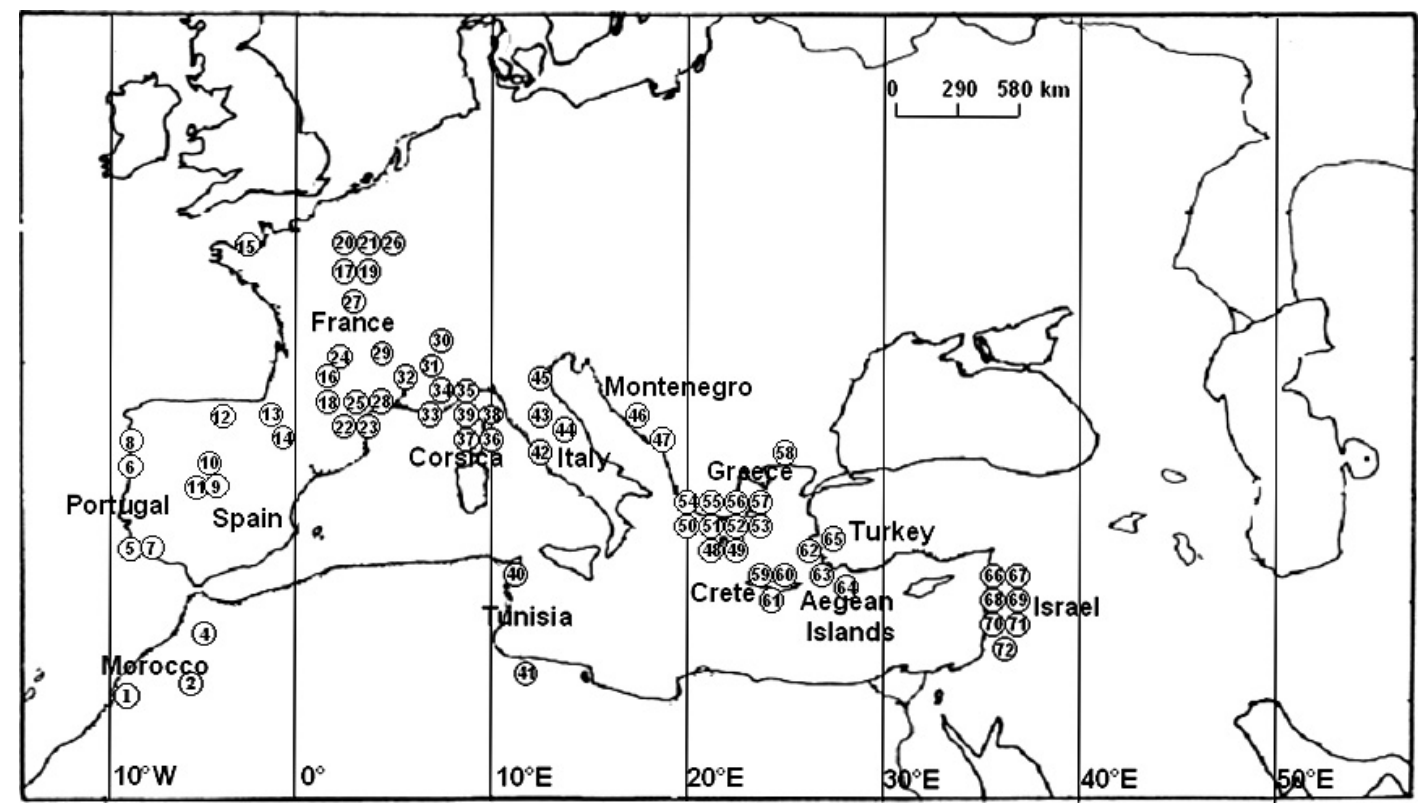

O. maculatus and a vertical black line from the top to the bottom of the pronotum for O. depressus) as proposed by Mulsant and Rey (1872), Dioli (1991), and Péricart (1998). Then, the cones were dissected scale by scale. The emergence holes of seed chalcids and the inner side of cone scales were examined for the presence of bug egg masses and (or) salivary tracks indicating the insertion of a rostrum between cone scales to feed (Battisti et al. 1999). The presence of egg masses was interpreted as an indication that the cone of the considered Cupressaceae species was suitable for oviposition, and the presence of bug salivary tracks indicated that the cone was suitable for bug feeding.

\section{Comparison of the life histories of $O$. maculatus and $O$. depressus under laboratory conditions}

The durations of egg and nymph development have already been identified for O. maculatus (Battisti et al. 1997). To determine the corresponding values for $O$. depressus, 15 males and 15 females of this species were collected in central France on $C$. sempervirens (site 17, Table 1) and reared together in a $30 \mathrm{~cm}$ $\times 30 \mathrm{~cm}$ aerated plastic box for one generation. Insects were fed with foliage of $C$. sempervirens bearing 3-year-old cones. Branches were changed weekly. The box was stored in a climatic chamber at $20{ }^{\circ} \mathrm{C}$ under $16 \mathrm{~L}: 8 \mathrm{D}$ conditions and checked daily for egg masses in cones and egg hatch to compare egg development patterns. We avoided handling of early-instar nymphs because they appeared very delicate. To assess the number of developmental stages, successive moults were recorded through daily sampling of nymphal exuviae in the box until all nymphs had reached the adult stage. For comparison, 30 males and 30 females of $O$. maculatus collected on $C$. sempervirens in southern France (site 34, Table 1) were reared under similar conditions.

An additional experiment used adults of O. depressus collected on Juniperus communis L. in southern France (site 24, Table 1). A total of 15 males and 15 females were reared under conditions similar to those described above but using branches of J. communis bearing 2-yearold mature cones. Feeding and egg laying were observed on cones, foliage, and branches. After 15 days of rearing, the juniper branches were replaced by branches of evergreen cypress. At the same time, adults of O. maculatus (15 males and 15 females from site 34 ) were reared on juniper branches bearing cones for 15 days.

\section{Life history of $\boldsymbol{O}$. maculatus under field conditions}

This study was conducted in a plantation of C. sempervirens in Italy, where a large pop- 
ulation of $O$. maculatus was previously recorded (Battisti et al. 2003). We used a family test, Fonte dei Seppi, located at Monte Morello, approximately $7.5 \mathrm{~km}$ north of Florence, Tuscany, Italy $\left(42^{\circ} 50^{\prime} \mathrm{N}, 11^{\circ} 15^{\prime} \mathrm{E}, 610 \mathrm{~m}\right.$ altitude), which is operated by the Institute of Forest Tree Pathology of Florence with the Italian National Research Council (CNR). The family test was planted in 1984 using 1-year-old seedlings, including 40 seedlings for each of 30 families. In 1998, we selected five half-sib families showing normally grown and apparently healthy trees. To survey the phenology of seed bug development, six trees in each family were randomly sampled every 15 days between 7 May and 30 November 1999 (i.e., 14 times). Each sample consisted of a random collection of 30 mature, 3-year-old cones and 30 overmature, 4-year-old cones. Sampled cones were stored at $5{ }^{\circ} \mathrm{C}$ until analysis, which was completed within 10 days of the date of collection. The partly opened cones, which may have contained bug nymphs, were individually put into plastic boxes, whereas closed or entirely opened cones were put together into a sealed plastic bag. Finally, all the cones were examined in the laboratory for the number of egg masses, nymphs at different developmental stages, and adult seed bugs.

\section{Comparative morphology of adults and nymphs of Orsillus seed bugs}

The frequency distributions of body and rostrum length were assessed for males and females of both species. Body and rostrum length were measured on 138 adult females and 186 males of $O$. maculatus and on 266 females and 258 males of $O$. depressus. We then calculated a rostrum length : body length ratio (hereafter, $\mathrm{R}: \mathrm{Bd}$ ) for each specimen. Different populations of seed bugs were used to evaluate the influence of geographical location on morphological variables. The effect of host on rostrum length was tested between populations within the same country: females of $O$. depressus were compared between host trees in France (sites 15-20, 24, 26, 27, and 30; Table 1), Morocco (sites 1 and 2; Table 1), and Portugal (sites 5, 6, and 8; Table 1). Populations of $O$. maculatus sampled on $C$. sempervirens from France, Italy, and Greece were compared for rostrum length (sites 32, 34-38, 43, 45, 59, 60, and 61; Table 1).

The morphological characters of nymphal instars were assessed in both species, using 17 to 30 nymphs of each of the developmental stages.
The nymphs originated from France and Italy. As in adults, body and rostrum length were measured for each nymph, and the $\mathrm{R}: \mathrm{Bd}$ ratio was calculated. Changes in nymph color were also recorded throughout development and compared between species.

Observations and measurements were made using a Leica ${ }^{\circledR}$ MZ12 stereomicroscope equipped with a Leica DC100 digital camera and Leica QWin ${ }^{\circledR}$ image processing and analysis software (version 2.3).

\section{Data analysis}

The relationship between the geographical coordinates (latitude, longitude) of sampled sites and the relative abundance (percentage of the total number of seed bugs observed) of each Orsillus species at those sites was tested using Pearson's correlation test (Zar 1999). Body length, rostrum length, and $\mathrm{R}: \mathrm{Bd}$ ratio observed in males, females, and nymphs at each developmental stage were compared between the two species using Student's $t$ test (Zar 1999). In parallel, the relationship between body length and rostrum length of individuals was tested using Pearson's correlation test. ANOVA was used to test for variation in adult size of both species throughout their distribution range. In this analysis, we used only the individuals sampled on $C$. sempervirens and pooled the data per country and per Orsillus species before analysis. ANOVA was also used to evaluate the effect of host tree on adult size. When necessary, data were transformed using either $\log (x+1)$ or arcsine transformation to satisfy normality and homoscedasticity requirements (Zar 1999). Analyses were conducted with the statistical software STATISTICA ${ }^{\circledR}$ for Windows, version 5.5 (2000) (StatSoft Inc., Tulsa, Oklahoma).

\section{Results}

\section{Geographical distribution and host range of Orsillus seed bugs}

Table 1 presents the numbers of Orsillus species sampled at each location. One of the two species was present at most sites. All samples from $C$. sempervirens in its native range (the eastern Mediterranean) and in continental Greece, Montenegro, and Israel contained only specimens of $O$. maculatus (Table 1). In the remainder of the introduction area of $C$. sempervirens, the relative abundance of $O$. maculatus decreased from east to west of the 
Fig. 2. Relationship between the mean $( \pm \mathrm{SE})$ abundance (percentage of total number of seed bugs sampled) of Orsillus maculatus on Cupressus sempervirens and longitude (increasing from west to east of the Mediterranean Basin).

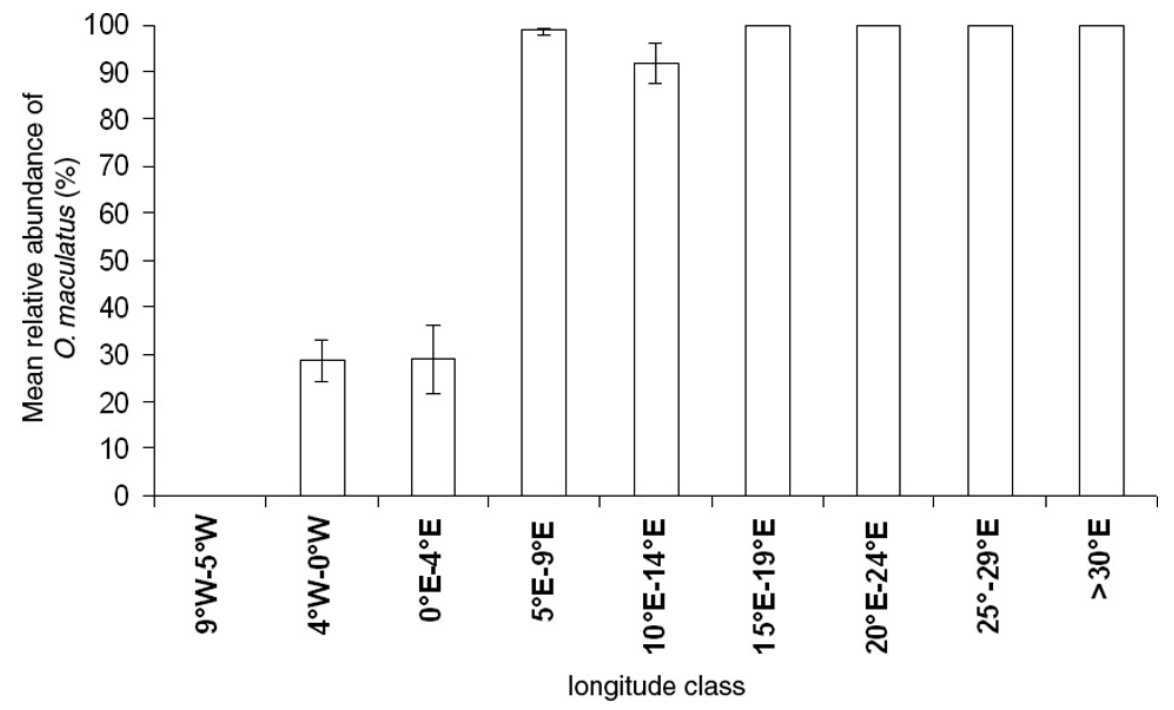

Mediterranean Basin, being negatively correlated with longitude (Pearson's correlation test: $r=0.77, P<0.05, n=51$; Fig. 2). In the central part of the Basin (Corsica, southeastern France, Italy, and Tunisia), O. maculatus was still largely dominant on $C$. sempervirens, representing an average of $99.4 \%$ of the sampled bugs, but this percentage decreased to $17.7 \%$ in the western part of the Basin (western France, Spain, Portugal, and Morocco), where O. depressus was the dominant species, as well as in northern France (Table 1). During this study, $O$. maculatus and $O$. depressus were observed for the first time on $C$. sempervirens in northern France and Portugal, and $O$. depressus was observed for the first time in Morocco.

Samples from other species of Cupressaceae were dominated by $O$. depressus (Fig. 3). Orsillus depressus was found on a native Moroccan cypress ( $C$. atlantica), introduced cypresses ( $C$. arizonica, Cupressus lusitanica Mill., and $C$. macrocarpa), native junipers (J. communis and J. phoenicea L. but not J. thurifera), and an exotic Port Orford cedar (Chamaecyparis lawsoniana (A. Murr.) Parl.), whereas only very low densities of $O$. maculatus were found on $C$. arizonica, C. atlantica, and C. lawsoniana, and none were found on junipers (Table 1). The relative abundance of $O$. maculatus was insignificant at all sites except two plantations of $C$. arizonica in southeastern France (sites 32 and 34), where this exotic species was mixed with C. sempervirens (Fig. 3). In contrast, $C$. arizonica was colonized by $O$. depressus only when isolated (site 4 in Morocco and site 9 in Spain). Orsillus depressus was especially abundant in a native stand of $C$. atlantica in Morocco, where it represented $92.2 \%$ of the sampled bugs (site 2), on J. communis (site 24) and $J$. phoenicea (site 48), and on the exotic species C. lawsoniana (sites 6-8). In southern Greece, a clear segregation was observed: at site 48, $O$. depressus was found only on $J$. phoenicea and O. maculatus was found only on $C$. sempervirens. Orsillus depressus was also sampled at a relatively high altitude in Morocco (site 2) and in France (site 30).

No Orsillus specimens were observed in the samples collected in California on native C. macrocarpa and in South Africa on introduced $C$. sempervirens, but a nymph of an unidentified Orsillus species was found in cones of native Chamaecyparis funebris (Endl.) Franco in China (Table 1).

On all Cupressaceae, seed bugs were found only on trees or shrubs bearing mature cones (i.e., cones in their 2 nd or 3 rd year of development). For example, O. maculatus was sampled at Vitrolles (site 33, Table 1) on the few C. sempervirens trees carrying cones, but no adults were sampled on the immature, nonflowering trees of $C$. atlantica. At Marcillac (site 24, Table 1), a total of 266 adults of 
Fig. 3. Comparison of the relative abundances (percentages of total number of seed bugs sampled) of Orsillus maculatus (open symbols) and $O$. depressus (solid symbols) on Cupressaceae species other than Cupressus sempervirens as longitudes increase from west to east of the Mediterranean Basin.

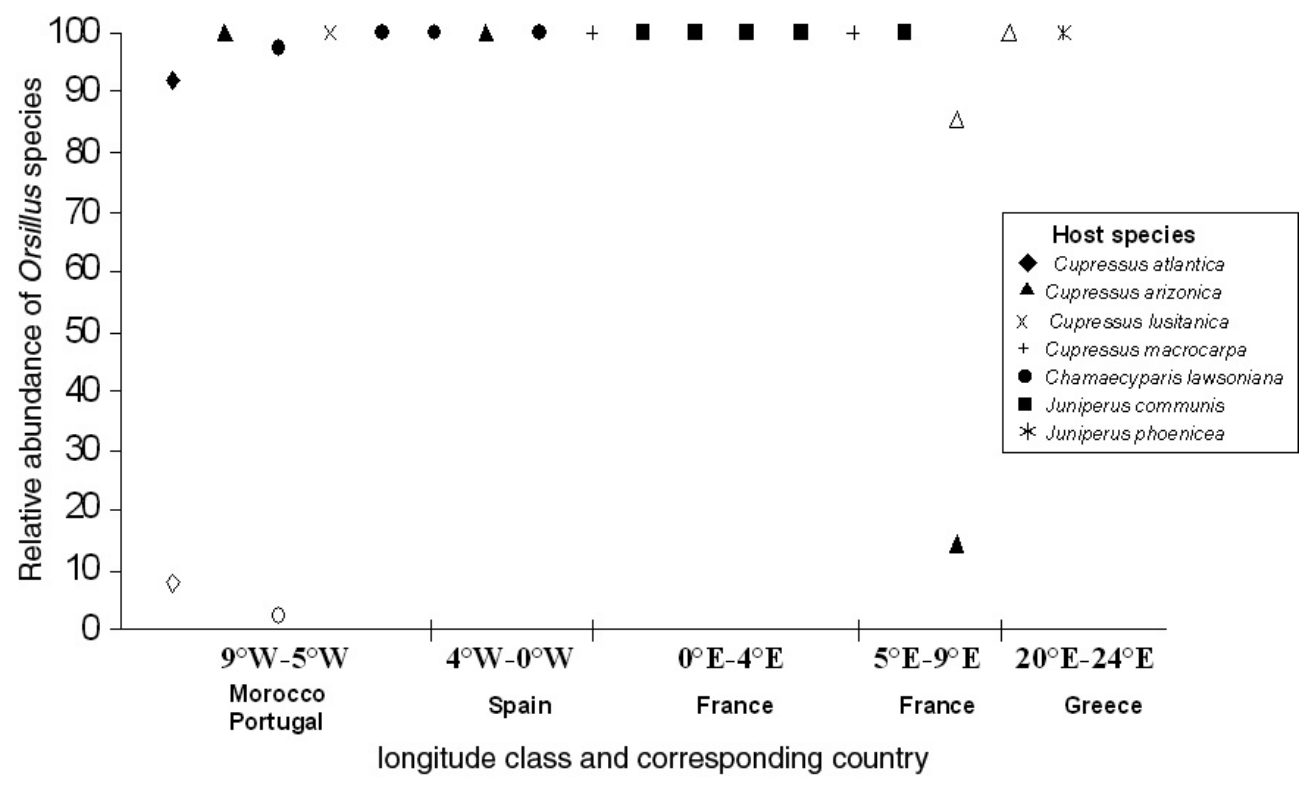

O. depressus were sampled on two J. communis shrubs bearing maturing berries in 2001. In contrast, no adults were found on the same trees in 2002 when those trees had no berries. A similar situation was observed on C. atlantica in a natural stand at Idni, Morocco (site 2, Table 1), where a large number of $O$. depressus and a few $O$. maculatus were sampled in 1998 on trees with 3-year-old cones but no bugs were found in 1999 when no mature cones were present.

\section{Comparison of the life histories of $O$. depressus and $O$. maculatus under laboratory conditions}

\section{Mating and feeding}

In both Orsillus species, mating occurs abdomen against abdomen, with the male shaking its abdomen from left to right in front of the female before mating. Under our laboratory conditions, females of $O$. depressus usually laid groups of eggs either in the emergence holes of $M$. wachtli or on the inner side of cone scales, as previously observed for $O$. maculatus (Battisti et al. 1997).

On $C$. sempervirens, O. depressus was observed to feed on seeds by inserting its rostrum between cone scales in a way similar to that of $O$. maculatus, leaving salivary tracks on scales. On J. communis, no salivary tracks were noticed on or in the cones, but $O$. depressus was observed to feed directly on the foliage. Salivary tracks were also noticed on the bark of $J$. communis. Adults of $O$. depressus collected on $J$. communis and reared in the laboratory on C. sempervirens fed on cypress cones, on which they oviposited within a week of the onset of rearing. In contrast, adults of $O$. maculatus collected from $C$. sempervirens did not survive more than a week when placed on J. communis in the laboratory, and no traces of feeding were observed.

\section{Egg development}

The duration of egg development was approximatively 19 days for both species (Table 2). Variation in egg coloration during embryo development was similar in $O$. maculatus and O. depressus. Eggs were light yellow immediately after oviposition but then became dark yellow, and red punctuations subsequently appeared within the embryo and at the site of future eyes. Just before hatching, embryos were yellowish red with many red punctuations. The head of embryos was always directed towards the aeromicropyles.

\section{Nymph development}

Just after hatching, first-instar nymphs were pinkish white, with legs and antennae always folded down along the body, and then became 
dark brown. The presence of translucent, empty chorions allowed us to locate the position of eggs on the cones once nymphs emerged. Firstinstar nymphs of $O$. maculatus were observed using the emergence holes of $M$. wachtli to enter the cypress cones. Under these laboratory conditions, $O$. depressus had five nymphal stages, as previously reported for O. maculatus (Battisti et al. 1997). Although the mean duration of complete nymph development was similar in the two species (53.6 days in $O$. maculatus versus 52.5 days in $O$. depressus), the development of specific nymphal stages was either longer (third and fifth instars) or shorter (first and fourth instars) in $O$. maculatus than in $O$. depressus (Table 2). Following each moult, nymphs were pinkish white but quickly turned dark brown with red punctuations. Nymph coloration lightened before each moult. There was no difference in coloration during nymph development that allowed differentiation of Orsillus species.

\section{Life history of $\boldsymbol{O}$. maculatus under field conditions}

All nymphal stages were observed in cones between May and October (Fig. 4). The mean number of nymphs in the first three instars of development was similar throughout the season (ANOVA: $F_{4,243}=1.81, P=0.12$ ), but there was a seasonal effect on the mean number of fourth- and fifth-instar nymphs in the cones $\left(F_{4,61}=2.5, P=0.04\right.$ ) (Fig. 4). More than 50\% of adults collected over the season were obtained in September, coincidently with the main period of oviposition. Eggs were laid during all seasons except winter (Fig. 5). Early-instar nymphs and adults sheltered in cones to overwinter (Figs. 4, 5).

The life history of $O$. depressus could not be precisely established in the field. However, we found egg masses on the cone scales of an isolated C. sempervirens in central France (Orléans La Source) in May 2000 and in cones of C. arizonica in Morocco in May 2002 (Table 1). No egg masses were ever found on C. lawsoniana and J. phoenicea, but a few eggs were found on cone scales of $C$. macrocarpa and under the cuticle of old cones of J. communis. For O. maculatus, egg masses and salivary tracks were observed with certainty only on $C$. sempervirens (Table 3). On $C$. arizonica and C. atlantica, either no egg mass was present or $O$. depressus was sampled together with $O$. maculatus so that we could not 
Fig. 4. Seasonal variation in the mean number of early-instar (L1L2L3: total of first, second, and third nymphal instars) and late-instar (L4L5: total of fourth and fifth nymphal instars) nymphs of Orsillus maculatus per cone of Cupressus sempervirens from May to October 1999 at Monte Morello, Italy.

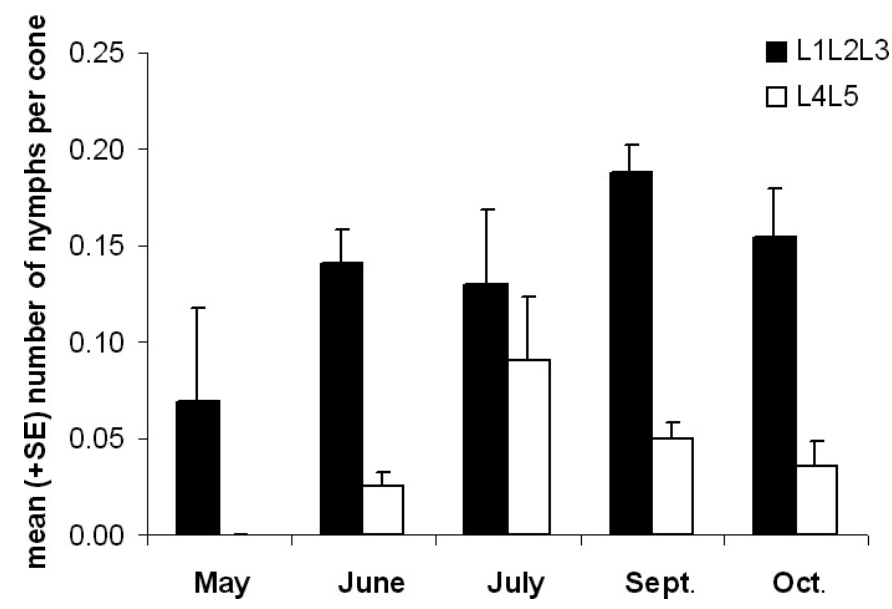

Fig. 5. Seasonal variation in the number of adults and fresh eggs of Orsillus maculatus per cone of Cupressus sempervirens from May to October 1999 at Monte Morello, Italy.

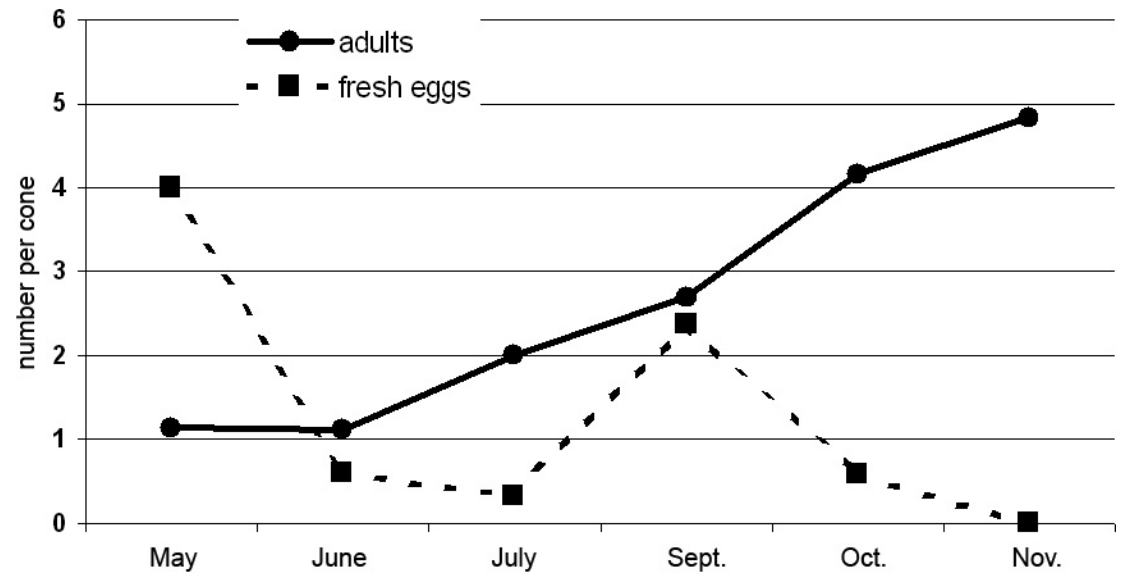

determine which species had laid the eggs (Table 3).

\section{Comparative adult morphology of adults and nymphs of Orsillus seed bugs}

Body length and length of the rostrum, as well as their ratio (R:Bd), were significantly lower in $O$. depressus than in $O$. maculatus for both males and females (Table 4). The length of the rostrum was significantly correlated with that of the body in adults of both species (O. maculatus: $r=0.90, P<0.05, n=324$; O. depressus: $r=0.77, P<0.05, n=524)$. There was no significant difference in the $\mathrm{R}: \mathrm{Bd}$ ratio between sexes in $O$. maculatus $\left(F_{1,324}=\right.$ 1.75, $P=0.19)$, whereas males showed a significantly higher ratio than females in $O$. depressus $\left(F_{1,524}=44.71, P<0.01 ; \mathrm{Ta}-\right.$ ble 4).

In O. maculatus, the rostrum length did not differ between females sampled in the native range of $C$. sempervirens in Greece and those sampled in the introduced range of the tree in Italy, France, and Corsica $\left(F_{3,135}=2.6, P=\right.$ $0.055)$. In $O$. depressus, the rostrum length did not differ significantly between females sampled on $C$. atlantica and those found on C. sempervirens in Morocco $\left(F_{1,36}=3.5, P=\right.$ 0.07). However, females of $O$. depressus living on $C$. sempervirens in France had a significantly longer rostrum than those found on J. communis and C. macrocarpa $\left(F_{2,168}=50.25\right.$, 
Table 3. Summary of host utilization by Orsillus maculatus and $O$. depressus in Europe and the Mediterranean area.

\begin{tabular}{|c|c|c|c|c|}
\hline \multirow[b]{2}{*}{ Tree species } & \multicolumn{2}{|c|}{ O. maculatus } & \multicolumn{2}{|c|}{ O. depressus } \\
\hline & Egg mass & Salivary sheath & Egg mass & Salivary sheath \\
\hline Cupressus arizonica & - & + & + & + \\
\hline$\overline{\text { Cupressus atlantica }}$ & + & + & + & + \\
\hline Cupressus lusitanica* & - & - & + & + \\
\hline Cupressus macrocarpa & - & - & + & + \\
\hline Cupressus sempervirens & + & + & + & + \\
\hline Chamaecyparis lawsoniana & $?$ & $?$ & $?$ & $?$ \\
\hline Juniperus communis & - & - & + & + \\
\hline Juniperus excelsa* & - & - & $?$ & $?$ \\
\hline Juniperus oxycedrus* & - & - & $?$ & $?$ \\
\hline Juniperus phoenicea & - & - & $?$ & + \\
\hline Juniperus thurifera* & - & - & $?$ & $?$ \\
\hline Thuja plicata* & - & - & $?$ & $?$ \\
\hline Thuja orientalis* & - & - & + & $?$ \\
\hline
\end{tabular}

Note: Exotic tree species imported from North America or Asia are underlined. ?, adult bugs recorded but no egg masses or salivary sheaths observed.

*Bibliographic data.

$P<0.01)$. Similarly, females sampled on C. sempervirens in Portugal had a longer rostrum than those found on $C$. lawsoniana $\left(F_{1,33}=39.08, P<0.01\right)$.

All sampled populations of $O$. maculatus exhibited a mean $\mathrm{R}: \mathrm{Bd}$ ratio higher than 0.85 for adult females, whereas this value was lower in populations of $O$. depressus (Fig. $6 a$ ). The interval $0.75-0.85$ contained fewer than $5 \%$ of the sampled females of $O$. maculatus. Based on body and pronotum color, we identified as $O$. maculatus an individual on $C$. atlantica with an $\mathrm{R}: \mathrm{Bd}$ ratio lower than 0.8 , but the smallest female we found originated from Italy on $C$. sempervirens (site 45). For $O$. depressus, the interval $0.75-0.85$ essentially corresponded to females that had $C$. sempervirens as host and originated from Spain, Morocco, and northern France (Fig. 6a).

The pattern was a bit different in males. Populations of $O$. maculatus showed a mean $\mathrm{R}: \mathrm{Bd}$ ratio higher than 0.85 in approximately $93 \%$ of the cases, whereas $96 \%$ of the males of $O$. depressus presented a lower value, although values ranged from 0.62 to 0.89 (Fig. 6b). The interval 0.79-0.89 included mostly males of $O$. depressus originating from the same sites as the females cited above (Spain, Morocco, and northern France, with $C$. sempervirens as host).

First and second instars of $O$. depressus had longer bodies and rostrums than those of
O. maculatus (Table 4). The differences in body size disappeared from the third instar on, but the rostrum was significantly longer in O. maculatus during the fourth and fifth instars. The $\mathrm{R}: \mathrm{Bd}$ ratio was significantly higher in $O$. maculatus than in $O$. depressus from the third nymphal instar (Table 4). The species can easily be differentiated from fourth and fifth instars (Fig. 7). From the fourth instar, 91\% of the measured $O$. maculatus nymphs had an $\mathrm{R}: \mathrm{Bd}$ ratio higher than 0.85 . For $81 \%$ of the nymphs of $O$. depressus that we measured, the $\mathrm{R}: \mathrm{Bd}$ ratio of fourth and fifth instars was lower than 0.85 (Fig. 7).

\section{Discussion}

Exotic tree species introduced into a new environment can be either accompanied by associated cohorts of insects from the original area or subjected to later colonization by indigenous insects that adapt to these new hosts (KrcmarNozic et al. 2000). The latter process generally implies the existence of preadaptations in the indigenous entomofauna (Frenzel et al. 2000). The human-mediated introduction of evergreen cypress, C. sempervirens, from Crete and the eastern Aegean Islands throughout the whole Mediterranean Basin probably began during the Roman period (Baumann 1982; Graniti 1998). Recent genetic studies showed that a seed 


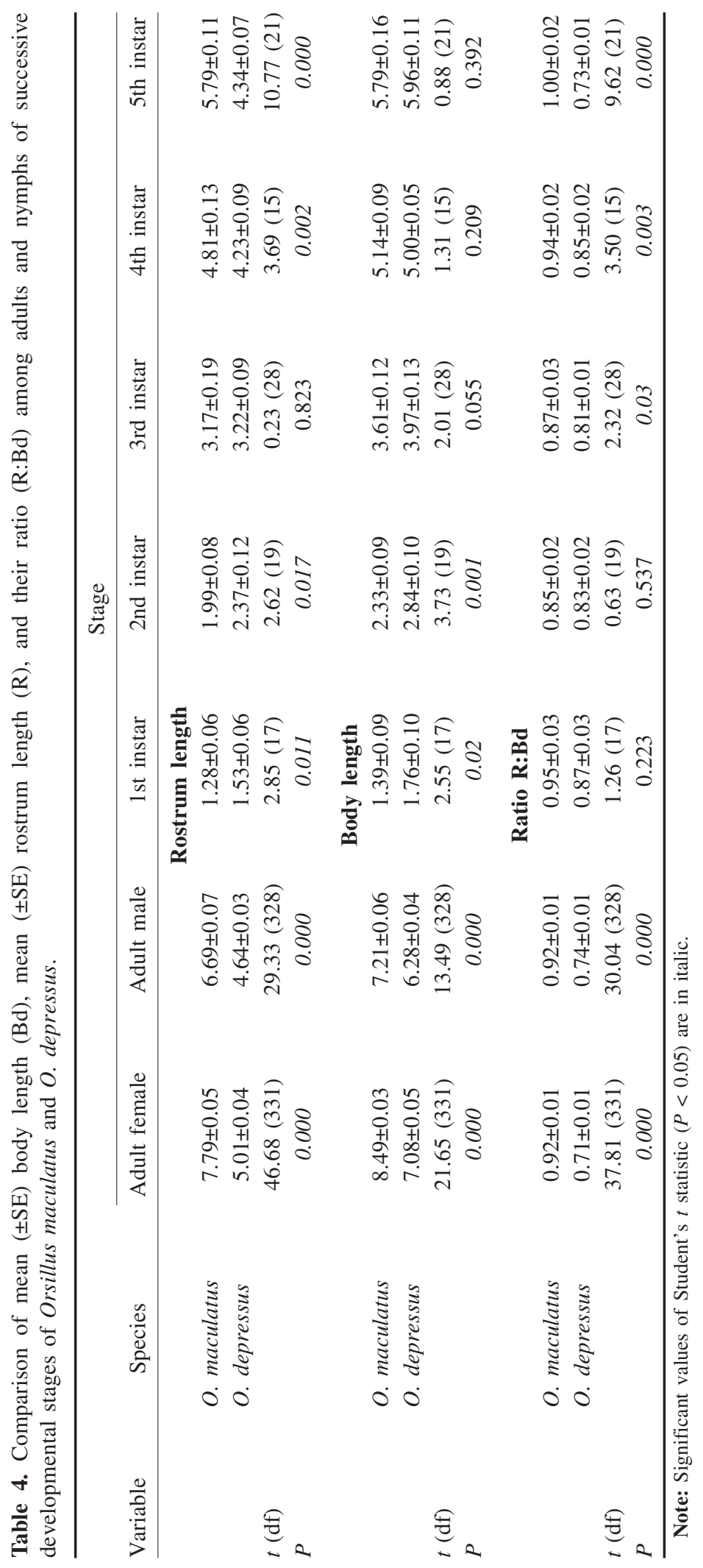


Fig. 6. Variation in the ratio of rostrum length to body length (R:Bd) for females $(a)$ and males $(b)$ of Orsillus maculatus (open boxes) and $O$. depressus (shaded boxes). Dashed and solid horizontal lines indicate the intervals within which the $\mathrm{R}: \mathrm{Bd}$ ratio is distributed for $O$. maculatus and $O$. depressus, respectively. Single individuals are indicated by a dash. Open circles represent individuals outside a normal distribution. Samples are ordered by site number (Table 1, Fig. 1). Host names are abbreviated as follows: Carz, Cupressus arizonica; Catl, C. atlantica; CM, C. macrocarpa; CS, C. sempervirens; Ch, Chamaecyparis lawsoniana; JC, Juniperus communis.
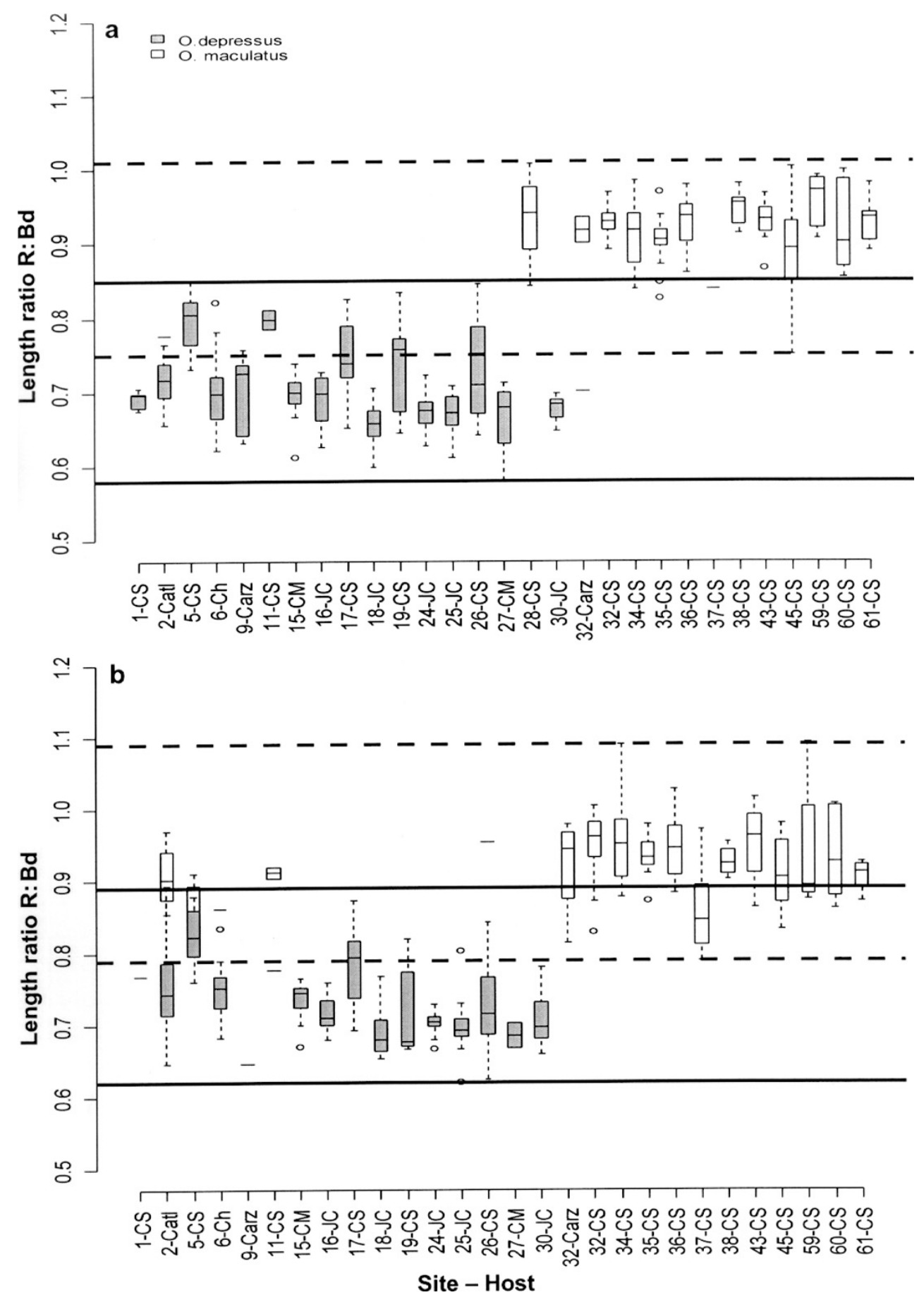
Fig. 7. Variation in the ratio of rostrum length to body length (R:Bd) among successive instars (L1 to L5) of nymphs of Orsillus maculatus (a) and O. depressus (b). Horizontal solid $(a)$ and dashed lines $(b)$ indicate the $\mathrm{R}: \mathrm{Bd}$ ratio of 0.85 that separates nymphs of $O$. maculatus and $O$. depressus (see text).

a)
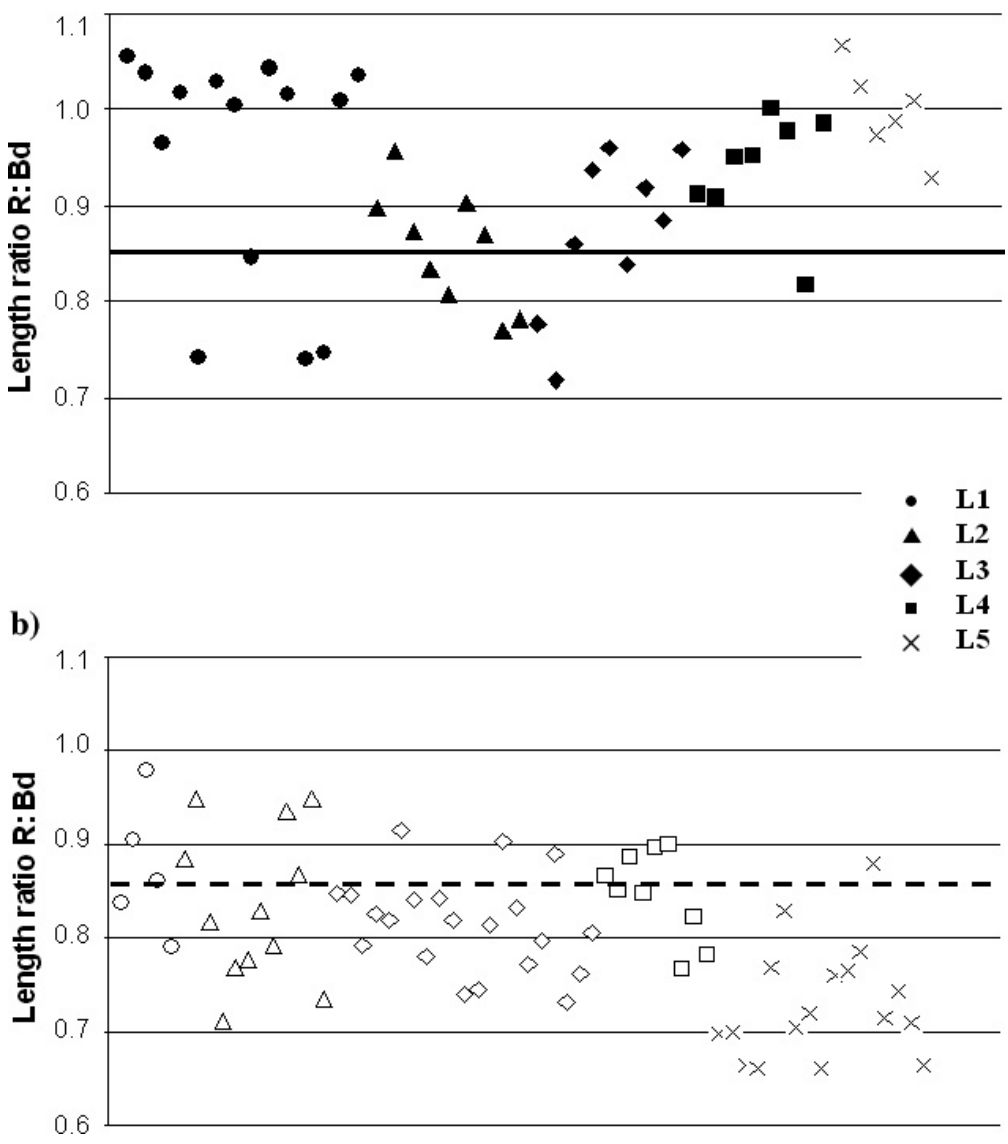

chalcid closely associated with C. sempervirens, $M$. wachtli, expanded from these eastern Mediterranean areas towards the west together with the introduction of the host (Roques et al. 1999a; Rasplus et al. 2000). Megastigmus wachtli is now established everywhere that $C$. sempervirens has been introduced in Europe (Roques and Skrzypczynska 2003). Increasing abundance of $O$. maculatus in cones of evergreen cypress along a longitudinal gradient from east to west suggests that the same process probably occurred for this species. The exclusive occupancy of cypress cones by $O$. maculatus within and near the native range of $C$. sempervirens, as well as the observation of $O$. depressus in the same area only on junipers, suggests a long-term association between $C$. sempervirens and $O$. maculatus but not $O$. depressus. In contrast, the domination of O. depressus in the western part of the
Mediterranean Basin, which probably corresponds to a more recent introduction of evergreen cypress, indicates that the colonization of the introduction range of $C$. sempervirens by $O$. maculatus is not yet complete. It also suggests that competition between seed bug species for seed cone exploitation could perturb this process. However, our survey confirmed that $O$. depressus, but not $O$. maculatus, is closely associated with native junipers such as J. communis and J. thurifera (Dupuis 1965; Roques 1983; Blasco-Zumeta 2000) in places where evergreen cypress has not been introduced in western Europe. Thus, O. depressus may have shifted from native junipers to C. sempervirens and, more recently, to the other exotic Cupressaceae. This tended to be confirmed by our rearing experiments, where $O$. depressus originating from junipers developed on evergreen cypress but the converse 
situation was not true for O. maculatus. However, given the large number of $O$. depressus individuals found in the native Moroccan range of Atlantic cypress, $C$. atlantica, we cannot exclude the possibility that $O$. depressus was first associated with this cypress and then moved east with junipers.

Both Orsillus species appear definitely linked to cones, since individuals were observed only on trees bearing maturing cones, although $O$. depressus can alternatively feed on foliage. The nearly identical durations of nymph development observed in the two species probably result from an adjustment to cone phenology, which is similar in most Cupressaceae, showing a 3-year reproductive cycle. This biological pattern may favor reciprocal shifts between Cupressaceae species.

Differences in bug morphology may also be important for cone exploitation because cone size is highly variable among Cupressaceae species. The significantly longer rostrum of adult $O$. maculatus may allow easier access to seeds within large cones such as those of $C$. sempervirens, whereas $O$. depressus, with a shorter rostrum, appears more closely associated with species with smaller cones such as Juniperus spp., Chamaecyparis spp., and C. atlantica. Such morphological adaptation to fruit size was observed for seed bugs feeding on seeds of the tree family Sapindaceae in the United States (Carroll and Loye 1987). Carroll and Boyd (1992) showed that the length of the buccal stylet in bug species of the genus Jadera Stal (Hemiptera: Rhopalidae) is correlated to the distance between the fruit surface and seed within the fruit. The bug species exploiting native Sapindaceae have a short buccal stylet, whereas those that have shifted to introduced Sapindaceae, which have bigger fruits, have a longer buccal stylet (Carroll et al. 1997). According to Carroll et al. (1997), the rapid differentiation of new seed bug species on the introduced hosts would have proceeded from both genetic and ecological processes. Adults of $O$. depressus found on $J$. communis in France had a shorter rostrum than those sampled on $C$. sempervirens, but rostrum length was not significantly different between the individuals sampled on junipers and those collected on an exotic cypress of Californian origin, C. macrocarpa, which presents the largest cones in the genus Cupressus. This suggests a more recent colonization of $C$. macrocarpa, probably by bugs shifting directly from junipers.

In the introduced area of $C$. sempervirens, both Orsillus species may occur on the same tree, but morphological variability of both adults and nymphs often hinders accurate identification of the species. Based on frequency distribution, measurement of the length of the rostrum relative to that of the body does not seem to necessarily result in an accurate identification of males, depending on host and geographical location. However, this measure does seem to constitute a diagnostic character for specific identification of fourth- and fifth-instar nymphs. When the $\mathrm{R}: \mathrm{Bd}$ ratio is above 0.85 , the species can be identified as $O$. maculatus, whereas the species is likely $O$. depressus when the ratio is below this value. When the $\mathrm{R}: \mathrm{Bd}$ ratio is between 0.75 and 0.85 , it is necessary to take into account the host tree and the geographical location.

Another striking difference between the two Orsillus species resides in the relationship between seed chalcids and adult bugs. All over the native and introduced range of C. sempervirens, a close association exists between $O$. maculatus and $M$. wachtli, the female bug ovipositing primarily in exit holes made by chalcids on the cone surface (Battisti et al. 1999; G. Rouault, unpublished data). Such an association was not observed on $C$. atlantica in Morocco: neither $O$. depressus nor $O$. maculatus oviposited in the exit holes of an endemic chalcid, Megastigmus atlanticus Roques et Skrzypczynska (Roques and Skrzypczynska 2003). Unfortunately, no data exist about the closely related species C. dupreziana and its entomofauna in the native Algerian range. We did not observe any eggs of $O$. depressus in the exit holes of a juniper seed chalcid, Megastigmus bipunctatus Swederus, on cones of J. communis in France. It is thus likely that the ternary association between $O$. maculatus, M. wachtli, and C. sempervirens developed a long time ago in the native range of $C$. sempervirens and then expanded progressively into new areas with the introduction of cypress. This behavioral association seems unique between seed bugs and seed chalcids. The seed chalcid Megastigmus spermotrophus Wachtl and the seed bug Leptoglossus occidentalis Heidemann (Hemiptera: Coreidae) share seed exploitation in Douglas-fir (Pseudotsuga menziesii (Mirb.) Franco; Pinaceae) cones, but bug egg laying appears 
independent of chalcid exit holes (Blatt and Borden 1998).

The introduction of North American species of Cupressaceae to Europe could have facilitated the geographical expansion of Orsillus spp. in a different way. Depending on the European country, such trees have been planted on a more or less large scale since 1900. Orsillus maculatus is diversifying in a limited way its host range and distribution area by colonizing plantations of $C$. arizonica and $C$. atlantica, but it has not yet shifted to species of other genera, with the exception of a unique individual found on Chamaecyparis sp. in Spain. In contrast, $O$. depressus has already colonized most of these introduced species all over western Europe and in the Mediterranean area. Although O. depressus seems more flexible in its choice of host for feeding, there is no clear evidence that it can effectively oviposit and completely develop on all of these exotic tree species. Colonization of exotic species could play an important part in the dissemination of the cypress canker pathogen, $S$. cardinale, as this fungus is considered to be primarily associated with the exotic species $C$. macrocarpa. Indeed, attack by fungi causes earlier opening of 3-year-old cones of C. sempervirens, allowing individuals of $O$. depressus (with short rostrum) to feed directly on seeds that are otherwise available only through cone penetration by the long rostrum of $O$. maculatus. Because adult bugs move from tree to tree to feed and lay eggs, the numerous man-made formations (plantations, ornamental trees, windbreak hedges) of exotic Cupressaceae, especially in urban and semiurban areas, may act as relays for Orsillus adults, thus allowing a probably faster dissemination of the fungal spores. From this point of view, the plantations surrounding the natural ranges of endangered native cypress species such as $C$. dupreziana and $C$. atlantica must be especially surveyed with regard to the expansion of Orsillus bugs that may carry spores responsible for cypress canker.

\section{Acknowledgements}

We thank J.P. Raimbault (INRA Orléans, France) for help with cone samplings and insect measurements. We are grateful to M. Ben Jamaa (Institut National de Recherches en Génie Rural, Eaux et Forêts, Ariana, Tunisia), M.A. El Alaoui El Fels (University of Marrakech, Morocco), N. Gillette (USDA
Berkeley, United States of America), S. Markalas (University of Thessaloniki, Greece), Z. Mendel (Agricultural Research Organisation, Bet Dagan, Israel), Y.Z. Pan (Southwest Forestry College, Kunming, China), P. Ramos (Istituto Superior de Agronomia, Lisboa, Portugal), D. Roganovic (Podgorica, Montenegro), and C. Ünal Alpetkin (Orman Fakültesi, Istanbul, Turkey) for supplying cone samples. G. Rouault was supported by a scholarship of the Région Centre in France and A. Battisti by the grant Ecocypre of the Trento district, Italy.

\section{References}

Aukema, B. 1988. Orsillus depressus nieuw voor Nederland en België (Heteroptera: Lygaeidae). Entomologische Berichten (Amsterdam), 48: 181183.

Barthelet, J., and Vinot, M. 1944. Notes sur les maladies des cultures méridionales. Annales des Epiphyties (Paris), 10: 11-23.

Battisti, A., Colombari, F., Frigimelica, G., and Guido, M. 1997. Life history of Orsillus maculatus, a true bug damaging seeds of Cupressus sempervirens. In Proceedings of the 5th Cone and Seed Insects Working Party Conference (IUFRO S2.07-01), Monte Bondone, Italy, September 1996. Edited by A. Battisti and J.J. Turgeon. Institute of Agricultural Entomology, Padova, Italy. pp. 215-220.

Battisti, A., Roques, A., Colombari, F., Frigimelica, G., and Guido, M. 1999. Efficient transmission of an introduced pathogen via an ancient insectfungus association. Naturwissenschaften, 86: 479483.

Battisti, A., Cantini, R., Feci, E., Frigimelica, G., Guido, M., and Roques, A. 2000. Detection and evaluation of seed damage of cypress, Cupressus sempervirens L., in Italy. Seed Science and Technology, 28: 199-208.

Battisti, A., Cantini, R., Rouault, G., and Roques, A. 2003. Serotinous cones of Cupressus sempervirens provide viable seeds in spite of high seed predation. Annals of Forest Science, 60: 1-7.

Baumann, H. 1982. Die grieschische Pflanzenwelt in Mythos. Kunst und Literatur. Himer Verlag, München.

Ben Jamaa, M.L., and Roques, A. 1999. Survey of impact on seed cones of two species of Cupressaceae, Cupressus sempervirens L., and Tetraclinis articulata Mast. in Tunisia. Arab Journal of Plant Protection, 17: 107-112.

Blasco-Zumeta, J. 2000. Contribution à l'étude de la faune assoviée à Juniperus thurifera L. dans Los Monegros (Aragon, Espagne). In Le Genévrier Thurifère (Juniperus thurifera L.) dans le bassin occidental de la Méditerranée: systématique, écologie, dynamique et gestion. Actes du colloque 
international de Marignac, Haute-Garonne, France, 26-27 September 1997. Edited by T. Gauquelin, J.-F. Asmodé, and G. Largier. Les Dossiers Forestiers No. 6, Office National des Forêts, Paris, France. pp. 94-103.

Blatt, S.E., and Borden, J.H. 1998. Interactions between the Douglas-fir seed chalcid, Megastigmus spermotrophus (Hymenoptera: Torymidae), and the western conifer seed bug, Leptoglossus occidentalis (Hemiptera: Coreidae). The Canadian Entomologist, 130: 775-782.

Bouaziz, K., and Chakali, C. 1997. Diversity and impact of cone and seed insects in Algeria. In Proceedings of the 5th Cone and Seed Insects Working Party Conference (IUFRO S2.07-01), Monte Bondone, Italy, September 1996. Edited by A. Battisti and J.J. Turgeon. Institute of Agricultural Entomology, Padova, Italy. pp. 193-207.

Cantini, R. 1997. Artropodi dei coni e dei semi del cipresso : osservazioni sulla biologia e sulle relazioni con funghi patogeni. Università degli studi di Firenze, Facoltà di Agraria corso di laurea in scienze forestali. Istituto di Patologia e Zoologia Forestale e Agraria, Italy.

Carroll, S.P., and Boyd, C. 1992. Host race radiation in the soapberry bug: natural history with the history. Evolution, 46: 1052-1069.

Carroll, S.P., and Loye, J.E. 1987. Specialization of Jadera species (Hemiptera: Rhopalidae) on the seeds of Sapindaceae (Sapindales), and coevolutionary responses of defense and attack. Annals of the Entomological Society of America, 80: $373-378$.

Carroll, S.P., Dingle, H., and Klassen, S.P. 1997. Genetic differentiation of fitness-associated traits among rapidly evolving populations of the soapberry bug. Evolution, 51: 1182-1188.

Cleu, H. 1950. Les faunes entomologiques méditerranéennes dans le bassin du Rhône et leurs rapports avec les éléments de la flore. Mémoires du Muséum National d'Histoire Naturelle, 30: 243-266.

Cleu, H. 1953. Biogéographie et peuplement entomologique du bassin de l'Ardèche. Annales de la Société Entomologique de France, 122: 174.

Colombari, F. 1996. Orsillus maculatus (Fieber) (Rhynchota Lygaeidae) su Cupressus sempervirens L.: attivita spermofaga e diffusione di funghi patogeni. Ph.D. thesis, Universita degli studi di Padova, Italy.

Dioli, P. 1991. Presenza di Orsillus depressus Dallas, 1852 nella zona alpina e osservazioni sulle specie italiane del genere (Insecta, Heteroptera, Lygaeidae). Il Naturalista Valtellinese, 2: 47-51.

Dupuis, C. 1965. Etude de l'oligophagie de trois punaises des Genévriers. Cahiers des Naturalistes, 21: $105-122$.

El Alaoui El Fels, M.A. 1997. Entomofauna of conifer seed cones in the western High Atlas,
Morocco. In Proceedings of the 5th Cone and Seed Insects Working Party Conference (IUFRO S2.07-01), Monte Bondone, Italy, September 1996. Edited by A. Battisti and J.J. Turgeon. Institute of Agricultural Entomology, Padova, Italy. pp. 21-26.

El Alaoui El Fels, M.A. 1999a. Les arthropodes liés à des conifères autochtones des Atlas marocains : biologie, distribution des principaux ravageurs des cônes et des graines et impact sur la régénération naturelle. Ph.D. thesis, Ecologie et Environnement, Université de Semlalia, Marrakech, Morocco.

El Alaoui El Fels, M.A., Roques, A., and Boumezzough, A. 1999b. Les arthropodes liés aux galbules et aux graines du genévrier thurifére, Juniperus thurifera L., dans les Atlas marocains. Ecologia Mediterranea, 25: 95-110.

Frenzel, M., Brändle, M., and Brandl, R. 2000. The colonization of alien plants by native phytophagous insects. In Proceedings of the 41st IAVS Symposium, Uppsala, Sweden, 26-31 July 1998. Opulus Press, Grangärde, Sweden. pp. 223225.

Garcia, B.A. 1998. Interaction between juniper Juniperus communis L., and its fruit pest insects: pest abundance, fruit characteristics and seed viability. Acta Oecologia, 19: 517-525.

Garcia, D., Zamora, R., Gomez, J.M., Jordano, P., and Hodar, J.A. 2000. Geographical variation in seed production, predation and abortion in Juniperus communis throughout its range in Europe. Journal of Ecology, 88: 436-446.

Graniti, A. 1998. Cypress canker: a pandemic in progress. Annual Review of Phytopathology, 36: 91-114.

Grasso, V. 1951. Un nuovo agente patogeno del Cup. macrocarpa Hartw. in Italia. Italia Forestale e Montana, 6: 62-65.

Guido, M., Battisti, A., and Roques, A. 1995. A contribution to the study of cone and seed pests of the evergreen cypress (Cupressus sempervirens L.) in Italy. Redia, 78: 211-227.

Hawkins, R.D. 1989. Orsillus depressus Dallas (Hem., Lygaeidae) an arboreal groundbug new to Britain. Entomologist's Monthly Magazine, 125: 241-244.

Kiritchenko, A.N. 1951. True bugs of the European Russia (Hemiptera) - keys and bibliography. Izdatel'stvo Akademii Nauk CCCP, MoskvaLeningrad. [In Russian.]

Krcmar-Nozic, E., Wilson, B., and Arthur, L. 2000. The potential impacts of exotic forest pests in North America. Canadian Forestry Service Pacific Forest Research Centre Information Report BC$\mathrm{X}-387 \mathrm{~F}$.

Lindberg, H. 1948. On the insect fauna of Cyprus. Results of the expedition of 1939 by Harald Håkan and P.H. Lindberg. II. Heteroptera und Homoptera Cicadina der Insel Zypern. 
Commentationes Biologicae Societas Scientarium Fennica, 10: 23-175.

Mulsant, E., and Rey, C. 1872. Etude sur les espèces du genre Orsillus. De la famille des Lygéens, ordre des Hémiptères. Annales de la Société linnéene de Lyon, 18: 203-211.

Péneau, J. 1927. Notes sur quelques Hémiptères de l'Anjou. Bulletin de la Société d'études Scientifiques d'Angers, 56: 99-103.

Péricart, J. 1998. Hémiptères Lygaeidae euroméditerranéens. Faune de France. France et régions limitrophes. Vol. 1. Fédération Française des Sociétés de Sciences Naturelles, Paris, France.

Ramos, P., and Caetano, F. 1999. Situaçoes preocupantes das Arvores em Jardins e Arruamentos de Portugal o cancro cortical dos Ciprestes. Silva Lusitana, 7: 249-256.

Rasplus, J.Y., Carcreff, E., Cornuet, J.M., and Roques, A. 2000. Genetic structure of the cypress seed chalcid Megastigmus wachtli (Torymidae) within its Mediterranean distribution. In Hymenoptera: evolution, biodiversity and biological control. Edited by A.D. Austin and M. Dowton. CSIRO Publishing, Collingwood, Australia. pp. 114-130.

Reichling, L. 1988. Punaises des Genévriers trouvées sur Faux Cyprès (Heteropt.). Entomologiste (Paris), 44: 46.

Roques, A. 1983. Les insectes ravageurs des cônes et des graines de conifères en France. INRA Editions, Paris, France.

Roques, A., and Battisti, A. 1999. Cypress insect pests. In Cypress. A practical handbook. Edited by E. Teissier du Cros, M. Ducrey, D. Barthelemy, C. Pichot, R. Giannini, P. Raddi, A. Roques, J. Sales Luis, and B. Thibaut. Studio Leonardo, Florence, Italy. pp. 74-95.

Roques, A., and Skrzypczynska, M. 2003. Seedinfecting chalcids of the genus Megastigmus Dalman, 1820 (Hymenoptera: Torymidae) native and introduced to the West Palearctic region: taxonomy, host specificity and distribution. Journal of Natural History, 37: 127-238.
Roques, A., Carcreff, E., and Rasplus, J.Y. $1999 a$. Cupressus sempervirens vs. cypress seed chalcid, Megastigmus wachtli: genetic and evolutionary relationships. In Proceedings of the IUFRO S7.01 Symposium "Physiology and genetics of treephytophage interactions", Arcachon, France, 31 August - 5 September 1997. Les Colloques de l'INRA 90. INRA Editions, Paris, France. pp. 6577.

Roques, A., Markalas, S.D., Roux, G., Pan, Y.Z., Sun, J.H., and Raimbault, J.-P. 1999b. Impact of insects damaging seed cones of cypress, Cupressus sempervirens, in natural stands and plantations of southeastern Europe. Annals of Forest Science, 56: 167-177.

Rouault, G. 2002. Biologie et répartition des punaises du genre Orsillus associées aux Cupressaceae: une étude de l'impact d'un pathogène introduit sur les interactions cônesinsectes. Ph.D. thesis, Université d'Orléans, France.

Rouault, G., Roversi, P.F., Cantini, R., Battisti, A., Bouaziz, K., and Roques, A. 2000. First record of an egg parasitoid (Telenomus gr. floridanus, Hymenoptera Scelionidae) of two true seed bugs (Heteroptera: Lygaeidae) living on Cupressaceae. Redia, 83: 163-173.

Schuh, R.T., and Slater, J.A. 1995. True bugs of the world (Hemiptera: Heteroptera): classification and natural history. Cornell University Press, New York.

Strout, R.G. 1970. Coryneum canker of Cupressus. Plant Pathology, 19: 149-150.

Teissier du Cros, E., Ducrey, M., Barthélémy, D., Pichot, C., Giannini, R., Raddi, P. et al. 1999. Cypress. A practical handbook. Studio Leonardo, Florence, Italy.

Wagener, W.W. 1939. The canker of Cupressus induced by Coryneum cardinale n. sp. Journal of Agricultural Research, 58: 1-46.

Zar, J.H. 1999. Biostatistical analysis. 4th ed. Prentice-Hall Inc., Upper Saddle River, New Jersey. 